\title{
Provisions of Celebrations in Islam from the Perspective of Shia and Sunni Jurists
}

\section{Sayyed Hossain Vaezi}

\author{
Assistant Professor, Department of Theology, Isfahan (Khorasgan) Branch, Islamic Azad University, Isfahan, Iran
}

Email: sh.vaezi@khuisf.ac.ir

\section{Zohreh Heydari}

M.A. in Fiqh and Principles of Islamic Law, Isfahan (Khorasgan) Branch, Islamic Azad University, Isfahan, Iran

Email: mhsadeghian@chmail.ir

\section{Doi:10.5901/mjss.2015.v6n2s1p393}

\section{Abstract}

As one of the most important psychological needs and due to its considerable effects on human life, happiness has always preoccupied human mind. Islam has paid attention to how one can have a healthy and happy life. Widespread effects, diversity of factors, excess, and negligence in regard with realization of happiness have made Islamic jurisprudence consider the issue seriously. It excess results in corruptions like promiscuity and its negligence also leads to some corruptions such as the misassumption that Islam agrees with grief and is against happiness. The present study was aimed at exploring the concept of happiness, understanding its significant place in life, figuring out its different categories, and examining various ways to express it based on the Holy Quran and infallible Imams' (AS) narratives (Hadiths). The study was conducted using a ....... method. The results of the study indicate that happiness is necessary and, like other human needs and behaviors, it has specific provisions and traditions whose observation can result in a healthy and happy community.

Keywords: celebration, happiness; Shia; Sunni

\section{Introduction}

Happiness is one of the human innate and psychological needs and it plays a significant role in many aspects of human life. Islam has paid as much attention to this issue as to all human physical and psychological needs. Presence of abundant Quranic ayahs, the Prophet's (PBUH) speeches, and Imams' (AS) narratives is evidence for such claim. The importance of happiness is supported by the fact that it is referred to in the Holy Quran 25 times and that a part of Imams' narratives entitled "Edkhal al-Sorur" (Happiness bringers) has been devoted to this issue. Moreover, those who bring happiness and joy to people are praised (MArdani Nokandeh, 2012: 108).

Research methodology which is used in present article is qualitative and data gathering is made through library research. Due to the lack of statistic data and non-measurable nature of the topic, the quantitative research was not possible.

Beautiful Allah is the creator of beauties and loves beauty, "Allah is beautiful and loves beauty". In regard with the importance of happiness in Islamic teachings, Allah the Almighty states in the Holy Quran, "They are happy with whatever Allah has given them of His grace, and they are happy for their followers and those who have not yet joined them, they face no fear and grief" (Al Imran/170).

Historically, human tendency to rejoicing and enjoyment is inherent. Therefore, we may find it in the conscience of all humans and it is constant in all eras. Due to its nature, this characteristic is conductible then it is possible to respond to this intrinsic need correctly.

\section{Discussion}

Happiness, meaning joy and prosperity, is one of the most important human psychological needs. Due to its remarkable effects on human life, it is highly significant. Its position, importance, causes, and effects on human life are devoted special attention in religious teachings, such that positive and purposeful happiness is frequently recommended in Islamic orders and Imams' (AS) narratives and Hadiths.

The main objective of the research is to review Islamic commandments regarding rules of happiness and 
celebration from the view point of Shi'a and Sunni scholars as well as the significance of happiness and its restrictions in Islamic factions.

The position and effects of happiness on individual and social life are highly recommended and discussed and it is introduced as an important issue for humans by Islam and the Holy Quran, it should be responded to in a correct way. Therefore, this divine religion does not advise reaching happiness and happiness in any way possible. How to attain happiness and the method to prepare appropriate situations to express it are frequently referred to in different ayahs and Imams' (AS) traditions (Kolini, 1986: 192; Zareian, 2013: 3).

Despite the fact that both happiness and grief are among human needs, some just pay attention to the former even when it is good to be sad and reduce happiness. On the contrary, some are always looking for grief and are sad even when they are supposed to be happy. However, it is not reasonable to replace our happiness with grief, and cause this assumption in the community that religion is equal to grief and melancholy. Therefore, if beauties and attractions of religion are highlighted, a more beautiful and attractive aspect of the religion will be depicted (Akbari, 2009: 45).

Therefore, the present study aims to respond to some questions like: Is Islam against any kind of celebration and happiness? How can we hold celebrations without committing a sin? What are the limits of happiness (especially family celebrations) from Shia perspective? What are the limits of happiness (especially family celebrations) from Sunni perspective?

\section{Necessity of Happiness}

Islam has deeply looked into all aspects of human life and provided plans and rules in accordance with his real and transcendent needs. It has also recommended happiness and happiness provoking factors that are necessary for a prosperous life. Divine orders of Islam include invaluable points about creating happiness. Happiness is sometimes provoked for oneself and sometimes for others. All recommendations about making others happy, wearing cheerful and bright clothes, pleasant smell, cleanliness, order and cleanliness, traveling and recreation, looking at nature, meadows and water, kindness and compassion, eliminating hatred, jealousy, humor and joking, and spreading happiness among people are aimed at creating a cheerful atmosphere and eliminating grief, which leads to revitalization for progress toward perfection (Tarighedar, 2004: 20).

The Holy Quran considers the presence of contradicting feelings in human heart like love and hatred, hope and fear, and happiness and grief as a sign of divine power and states, "He is who makes [us] laugh and sweep" (AnNajm/43).

Islam is an eternal school and religion that has provided a plan for prosperous life for all generations and all over the world. It is so comprehensive and rich that provides appropriate responses to all human psychological and physical needs (Seifuri et al, 2011: 88). Happiness is one of the human psychological needs that are originated from nature, entity and creation of human. Allah-centeredness is one of the most important criteria of happiness and happiness, which is referred to in the Holy Quran. Therefore, in some ayahs Allah invites the Muslims to happiness. Muslims' happiness as a result of Allah's grace and mercy is praised in the Holy Quran (Zini Malak Abad et al, 2011: 55). "Tell them to be happy for Allah's grace and mercy, which is better that what they have collected" (Ynus/58).

Islam invites its followers to positive and beneficial happiness and happiness because taking advantage of enlivening activities at the right time with considering necessary limits is very effective in revitalization and reduction of life monotony. This theme that making a brother Muslim happy is a great worship is referred to in different forms in narratives. The theme of some narratives is that the best and most favorite worship to Allah the Almighty is that a Muslim makes his brother Muslim happy, or in other words "brings happiness to his heart".

However, for approaching to happiness we first need to have a precise understanding about its concept and distinguish its types. Happiness can generally fall into two categories: healthy and real happiness and false and unreal happiness. Islam and other divine religions have introduced happiness as a human good and honorable deed and recommend it to their followers; however, they seriously warn about false and unreal happiness. Islamic texts classify happiness into two categories of valid, stable, and positive happiness and unstable and negative happiness. Therefore, those kinds of happiness that do not disturb stable ones are called valid and positive (Mohammadi Rey Shahri, 2007: 26).

\section{Types of Happiness}

Like all human desires, Islam has also paid attention to happiness (Motahari, 1975: 56-57). It should be noted that happiness is not limited to material happiness and there is spiritual happiness. Happiness that is involved with musing and singing is related to the period of intellectual and emotional immaturity of human, but human will reach a period when 
he benefits from spiritual happiness. Examples of the latter type of happiness include happiness resulted from a discovery or an invention, scientific happiness, and so on (Abedini, 2011: 181).

\subsection{Acceptable happiness}

Since human is instinctively seeks happiness, its instances and limitations should be explained and clarified because some believe that they can bring happiness for themselves by accumulating wealth, listening to vulgar music, attending meetings of sin and corruption, and wearing jewelries. However, acceptable happiness in Islamic perspective is the one that has a divine orientation or be a pathway to performing religious duties because in Islamic ideology and teachings, the real acceptability is nearness to Allah and all human deeds and actions should be done accordingly, so that he reaches perfection.

Some properties of acceptable happiness:

A. It should not be involved with sin. Imam Sadiq (AS) stated, "It is not right for a Muslim to attend a meeting where the people are committing sins and he cannot tolerate the situation" (Majlesi, 1989: 199).

B. It does not cause negligence of Allah. "Do not cause Allah's wrath for pleasing anyone and do not approach people by falling apart from Allah" (Horameli, 1988: 422).

C. Moderation should be observed in it. Imam Ali (AS) stated, "Muslim's happiness is when he obeys Allah and his grief is when he commits a sin" (Amadi, 2002: 5594).

\subsection{Unacceptable happiness}

Human is naturally willing to be happy in the world. This happiness can be experienced through different ways. Sometimes it is followed by long grief which is against the human goal of perfection or it is associated with sin, fun, waste of time, excitement, and harassment of others. According to the holy religion, this type of happiness is indecent and unacceptable and Muslims must avoid it. Happiness that begins with a sin can be an example of this type. Although human may be happy because of that sin, it brings about consequent troubles. The Holy Quran considers unacceptable happiness as counter value that is involved with sin, negligence, and corruption (Seifuri et al, 2011: 100). In this regard, Allah states in the Holy Quran, "If feel happy, the feel sad and if you are hurt, they get happy. And if you be tolerant and righteous, you will not be hurt. Undoubtedly, Allah knows whatever they are doing" (Al Imran/120).

Here, some examples of unacceptable happiness according to Islamic view are presented.

A. Happiness over sin: Someone who is happy with sin and disobedience to Allah is committed two indecent actions: first the sin and the second happiness over the sin. In a narrative, Imam Sajjad (AS) stated, "Do avoid being happy over your sin because happiness over sin is a worse and bigger guilt than the sin" (Majlesi, 1989: 159).

B. Happiness over other's sin: Imam Ali (AS) stated, "Do not be happy over other's sin because you do not know what the world brings to you" (Rey Shahri, 2012: 210).

C. Ridiculing happiness: A negative type of happiness is happiness over ridiculing others. This type of happiness is caused by belittling and weakening the right like Pharaoh's laughter at rational reasons and miracles of Prophet Musa (AS). In this regard, the Holy Quran states, "As he [Prophet Muhammad] revealed our ayahs, they ridiculed hem and laughed" (Al-Mutaffifeen/29) (Makarem, 1995: 79).

D. Proud happiness: After impulsive individuals reach wealth and power, they indulge in happiness in a way that they ravish. This method of happiness is also unacceptable according to the Quran. The Holy Quran talks about Korah, "Korah was a rich man in Musa's tribe who oppressed the people. We gave him a lot of treasure and wealth. Carrying the keys of his treasures would make his men tired" (Al-Qasas/76).

E. Happiness over sad and mournful people: Imam Hassan Askari (AS) stated, "Happiness over sad and mournful people is not polite and human" (Majlesi, 1989: 374).

F. Happiness with lying: The Prophet Muhammad (PBUH) said, "Shame on someone who tells lies to make people laugh! Shame on him, shame on him, shame on him" (Majlesi, 1989: 88).

G. Happiness in frivolous parties: Holding frivolous parties and the resulting happiness are among unacceptable types of happiness which are usually associated with sins. Although Islam wants happy and lively lives from people, it is against sins and guilt (Mohammadinia, 2012: 214). 


\section{Jurisprudential Provisions of Celebration and Happiness}

Islam is not against happiness but is its best promoter. However, it recommends a type of happiness which is not involved with sin or corruption and in which Islamic traditions are observed. Therefore, in accordance with the goal of life, Islam believes that happiness has limitations. The content of happiness, its form, and causes should not be in contradiction with human soul. In fact, happiness is not a goal itself but a means to help human reach perfection (Zareian, 2013: 29). Examples of acceptable happiness are: Imams' (AS) birthday, birthdays, and weddings. How these celebrations are held should be taken into consideration. There is no doubt that music and singing that are proper for frivolous parties are considered as haram (Illegal) by Islam. However, this case should be taken into consideration for weddings and other celebrations that have been considered as exceptional. There are different narratives on weddings and other celebrations in Prophet's (PBUH) time like Fatima's (AS) wedding or people's celebration at Prophet's arrival to Medina. The most outstanding form of happiness that was common among the early Muslims consisted of singing and playing the Daf; however, dancing and playing other musical instruments are less referred to (Ghazizadeh, 1995: 329).

\subsection{Provision of vocal from Shia perspective}

It should be noted that music and vocal are different in jurisprudential terminology. Vocal refers to a singing that comes out of the larynx and is turned in the throat. It makes the listener excited and cheerful and is suitable for frivolous parties. Music; however, is a sound that is produced with musical instruments (Hosseini, 2009: 169).

As the jurists do not agree over the issue of vocal, its provision is also controversial. In this regard, jurists can be divided into three groups (Golshadi, 2013: 12-14):

A. Some consider vocal as absolutely haram and believe that inherit dignity of vocal is so certain that it cannot be specified (Ameli, 1998:179).

B. Some others consider vocal as total haram, but there are some exceptions.

C. Some did not consider vocal as haram, but they believe there are no ayahs or narratives on its respect.

\subsection{Provision of vocal from Sunni perspective}

Sunni jurists do not agree over vocal. Here, their views are presented according to the four sects of Sunni.

\subsubsection{Provision of vocal from the perspective of Hanafis}

Some Hanafi scholars believe that vocal is haram. Tabari narrated from Abu Hanifa that he considered vocal as haram and listening to it is a sin. Some other Hanafis consider it to be halal (Legal) unless it is mixed with a haram like lyrics that describe a known teenager or a woman. If such a vocal does not contain haram words like describing wine and bondwomen, it is undoubtedly acceptable and there is no debate on the fact that it is halal; however, it is likely that it is recommendable like the vocal of Shotorbans (Someone who leads the camels in a caravan) in Hajj caravan.

\subsubsection{Provision of vocal from the perspective of Malikis}

Jurists do not agree over Maliki's views. Some believe that he considered vocal as haram. Ghazi Tabari stated, "Maliki interdicted listening to vocal. He believed that vocal directs human toward stupidity and sin". However, there is another narration from Malik, based on which he considered vocal as ugly and religiously sanctioned. Toosi, Maverdi, Abu Mansoor Forani, and Ghaffal have reported that he [Maliki] believed that vocal is detestable or religiously sanctioned. In the book "Ihya al-Olum al-Din" (Revival of religious sciences), Ghazali stated, "If someone buys a bondwoman and recognizes that she is a vocalist, he can return her" (Golshadi, 2013: 29).

\subsubsection{Provision of vocal from the perspective of Shafi'is}

Some Shafi'i jurists believe that vocal is haram. Tabari, Halimi, Jarjani, Ghartabi, and Ibn Ghim Jozi are among these jurists (Meysami, 1985: 2310). However, some Shafi's believe that vocal is halal. Ghazali, Maverdi, and Toosi reported vocal to be religiously sanctioned. According to Ghazali, vocal has different categories and a vocal that does not bring about any haram is not haram. In his book "Ihya al-Olum al-Din", Ghazali narrates from Shafi'i's book "Adab al-Ghaza" (Etiquette of the judiciary) and writes that vocal is a frivolous and religiously sanctioned matter and someone who 
indulges in it will become stupid and his witness is not acceptable. Judge Abu Tayyeb stated that listening to vocal of a namahram (Someone who one can marry) woman is no acceptable at all in Shafi'i, whether she is wearing a veil or not and is free or a slave. He narrated from Shafi'i that if the owner of a bondwoman collects people to listen to her vocal, he is stupid and his witness is not acceptable. He also narrated from Shafi'i that he did not like the sound of flute and stated that Zandiqs (Muslims who hold views or follow practices that are contrary to central Islamic dogmas) have developed it so that they can stop people from the Quran" (Golshadi, 2013: 30).

\subsubsection{Provision of vocal from the perspective of Hanbalis}

Hanbali jurists do not agree over vocal. Many of them believe that it is religiously sanctioned and some considered it as haram. Jorizi has narrated from the book "al-Figh ala al-Mazahib al-Arba'a" (Figh in the four doctrines), Toosi has narrated from the book "Khalaf" (Disagreement), and Zohaili has narrated from the book "al-Fiqh al-Islamiya wa Adala" (Islamic Fiqh and argumentation) and reported that vocal is religiously sanctioned and unacceptable (Meysami, 1985: 2313). However, some Hanbalis believe that vocal is haram. Ibn Ghayyem Jozi in his book "Kashf al-Nitha" (The cover revealed), Ghartabi in his book "al-Jami' al-Ahkam al-Quran" (The collection of Quranic rules), and Ibn Ghidama in his book "al-Mughanni" (Lyrical) have reported this order from Hanbali.

\section{Islamic Celebration from Shia Perspective}

One of the ways to keep important historic and religious events of Islam alive is through celebrating and appreciating religious rituals that are originated from Islamic teachings and the prophets and Imams' lives and indicate triumph over lust and obedience from divine orders. Examples of these rituals and celebrations are Ghadeer, Eid al-Adha, Eid al-Fitr, and the Prophet's (PBUH) Revelation.

These rituals establish a kind of security and peace and enhance the Muslims' spiritual capacity. They also prevent false celebrations and discourage the youth from negative issues. Therefore, celebrating these rituals in the Islamic community is a necessity. Celebrating these rituals helps us not forget whatever has happened in Islam's history and how it has developed.

Creating a happy and lively spirit and paying attention to Imams' (AS) recommendations in these days can result in a better understanding of Islam. In these celebrations, along with creating happiness, Imams' (AS) rank and dignity should be discussed in order to raise people's knowledge and awareness.

\section{Islamic Celebration from Sunni Jurists' Perspective}

From Sunni perspective, celebrating some rituals and Eids is heretical and unacceptable but celebrating some other is acceptable. For instance:

A. Wedding: Prophet (PBUH) has forbidden secret marriage and ordered it should be held in public. Therefore, celebrating wedding is acceptable provided that unacceptable music is not played and namahram men and women do not gather in a place.

B. The three Eids of al-Adha, al-Fitr, and Friday are acceptable.

C. Birthday and other cheerful celebrations like the first day of Lunar year, Christmas, Sha'ban midnight celebration, birthday of the Prophet (PBUH), and coronation or presidency were not common during the first three centuries of Islam; therefore, these celebrations are heresies among Muslims and are unacceptable.

However, according to Imams' (AS) narratives, happiness should have limits and regulations because we believe in the Origin and the Resurrection. Islamic scholars have criticized excess and negligence in the debate of happiness because excess turns the happiness into sin and waste of time and negligence brings about sadness and melancholy.

\section{Conclusion}

Human nature is divine. He is instinctively bound to happiness. The Holy Quran considers happiness as a natural need. It also provides necessary guidance and rules for happiness and shows the correct way to satisfy it. It should be noted that Islam does not approve of any way to reach happiness and there are frequent reference as to how to appropriately reach it. Examples of happiness are parties and celebrations that are held in different occasions. Islam wants its followers to live a happy life but it is not right to be happy in unacceptable ways. There should be some limits for it. From a religious perspective, happiness falls into two categories of acceptable and unacceptable happiness. Islam is not against the 
former. It is likely that acceptable happiness is awarded.

Moreover, acceptable cheerful celebrations should have some conditions and properties like: First, they should not be associated with sin and guilt, as Imam Sadiq (AS) said, "Do not cause Allah's wrath for pleasing anyone and do not approach people by falling apart from Allah" (Horameli, 2001: 422). Second, they should not be involved with harming and ridiculing others like turning the music up, recreational explosions, and wedding caravans that disturb people in the midnight, which are against Islamic principles. In this regard, the Holy Prophet (PBUH) said, "Someone who hurts a Muslim has hurt me, too" (Majlesi, 1989: 72). Third, they should not be frivolous. In Islam, activities that stop spiritual progress are forbidden. An activity that stop a Muslim's from paying attention to Allah and resurrection is harmful.

\section{References}

Akbari, M. (2008). Sadness and happiness in Imams' (AS) tradition. 3rd ed. Safhe Negar Publication: Ghom.

Amadi, (2002). Exalted Aphorisms and Pearls of Speech. Translated by H. Imani. $4^{\text {th }}$ ed. Boostan-e Ketab Publication: Ghom.

Horameli, M. (1988). Wasail al-Shia. Al al-Beit (AS) Publication: Ghom.

Hosseini, M. (2009). Music provisions (Appendix dancing and gambling). $6^{\text {th }}$ ed. Maarif Publication: Gom.

Zareian, Z. (2013). Jurisprudential investigation of happiness types and how to reach them. Unpublished M.A. thesis. Islamic Azad University of Najafabad.

Zini Malak Abad, H. \& Nil Sazan, N (2011). The place of happiness in the Quran and Narratives. Culture in Islamic University, 1(1).

Seifuri, V. \& Falahati, A. (2011). Investigating the importance of happiness according to the Holy Quran, Narratives, and religious teachings. Culture in Islamic University, 15(4).

Tarigheh Dar, A. (2004). Sharia and happiness (Figh perspective about dancing, clapping, and happiness). Hozour Publication: Ghom.

Abedini, A. (2011). Happiness in Islam. Bayyenat Journal, 192. Noor Data base of Specialized Journals.

Ameli, M. (1998). Dignity key. vol. 4. Al al-Beit Publication: Ghom.

Ghazizadeh, K. (1995). Vocal in Islamic perspective. Figh Journal, 4-5.

The Holy Quran

Kolini, M. (1986). Kitab al-Kafi. vol. 4. Translated by J. Mostafavi. vol. 1. Ahl al-Beit Publication: Tehran.

Golshadi, Z. (2013). Investigation of woman singing according to Imami Figh and public. Unpublishe M.A. thesis. Islamic Azad University of Najafabad.

Majlesi, M. (1989). Bahar al-Anwar. vol. 107. Tab and Nashr Publication: Beirut.

Mohammadi Rey Shahri, M. (2012). Zamzam Irfan. Dar al-Hadith Publication.

Mohammadi Rey Shahri, M. (2007). Mizan al-Hikma. 9-volume Edition.

Mardani Nokandeh (2013). The nature of happiness in Islamic teachings. Bayyenat Journal, 8(76).

Motahari, M. (1975). Hidden helps in human life. Comprehensive Database of Morzeza Motahari.

Makarem Shirazi, N. (1995). Nomuneh Interpretation. vol. 21. Islamic Books Publication: Tehran. 